\title{
RÉPLICA AL ARTÍCULO DE DON JOSÉ LUIS VALLARTA MARRÓN
}

\author{
Romualdo BERMEJO GARCÍA* \\ Carlos RuIZ MigueL**
}

Siempre es agradable que los trabajos publicados puedan tener repercusiones en las opiniones de los que compartimos unas mismas preocupaciones. Discrepar de las opiniones de los demás no sólo es legítimo, sino también conveniente y positivo para el desarrollo del derecho y de la ciencia en general. Dicho esto, lo primero que queremos dejar claro al autor es que estos españolitos de a pie no hemos recibido un euro del gobierno del señor Aznar por defender nuestras tesis. Le podrán gustar o no, pero no conviene confundir la ética intelectual y el savoir faire académico con la política. El autor, que parece haber sido embajador de México, comete un grave desliz al lanzarse en esa clase de diatribas. No sabemos si lo hace por devoción o por convicción, pero le podemos asegurar que nosotros nunca hemos representado ni al gobierno español ni al Estado español, como lo ha hecho usted con su país, aunque ello no empece para que nos consideremos españoles. Si usted piensa que hemos sido clientes de Aznar, no sólo está equivocado, sino que está en un craso error...Y nos sorprende con la facilidad que lo insinúa, como si no pudiera haber personas que piensan de distinta manera a la suya. No es pre-

* Catedrático de derecho internacional de la Universidad de León.

** Catedrático de derecho constitucional de la Universidad de Santiago de Compostela. 
cisamente eso lo que nosotros pensamos de usted, aunque sí que parece defender las tesis que en su día defendió su gobierno. ¿Acaso puede usted hacerlo y nosotros no? El gobierno de Aznar fue el gobierno de todos los españoles, y por lo tanto también el nuestro. A usted a lo mejor no le gustó, pero eso es cosa suya.

Por lo demás, es obvio que no hay que rasgarse las vestiduras por la diversidad de opiniones. Personalmente el profesor Bermejo comparte su tesis de que la Guerra de los Seis Días se llevó a cabo de conformidad con la legítima defensa ${ }^{1}$ aunque también debemos decirle que de todos los autores que usted cita en su trabajo, creemos que ninguno comparte nuestra opinión. Y también le decimos que todo apunta a que algunos están cambiando ahora de opinión. Con esto, lo que queremos subrayar es que las opiniones son libres, y todo el mundo tiene el derecho a opinar razonablemente sobre cuestiones que no siempre están tan claras como algunos pretenden. Por ejemplo, el señor Vallarta parece considerar que los análisis anglosajones sobre esta materia son vetustos, y en este ámbito parece situar las tesis defendidas en nuestro trabajo. También parece ver muy claro a nivel internacional el régimen jurídico en materia de uso de la fuerza, aunque si eso fuera así, no se habrían escrito miles de obras sobre el tema. Y si todo estuviera tan meridianamente claro, no estaríamos ahora debatiendo como lo estamos haciendo. Es más, siempre es preocupante constatar cómo en diversos ámbitos se critica de manera irracional al mundo anglosajón para luego terminar siguiendo sus tesis. ¿Por qué van a formarse al Reino Unido y sobre todo a los Estados Unidos miles de ciudadanos europeos y de su país? ¿Acaso vuelven, los que vuelven, con tesis vetustas? ¿Son vetustas las tesis que propician defender los derechos humanos y las libertades cuando estas son perseguidas por Estados que tienen el concepto de soberanía decimonónico? Como decía Guy de Lacharrière, cuando la norma se aparta desmesuradamente de la realidad, algo grave está ocurriendo, sobre todo si esto ocurre en materia de uso de la fuerza, que era el ámbito en el que se centraba el citado autor. ${ }^{2}$

1 Véase Bermejo, Romualdo, El marco jurídico internacional en materia de uso de la fuerza: ambigüedades y límites, Madrid, Civitas, 1993, pp. 303 y ss.

2 Véase Lacharrière (de) G., "La réglementation du recours à la force: les mots el les conduites", en varios autores, Le droit des peuples à disposer déux-mêmes. Mélanges offerts à Charles Chaumont, París, 1984, pp. 350 y 351. 
Por lo demás, el señor Vallarta tampoco parece estar de acuerdo con que el Consejo de Seguridad reconociera el derecho de legítima defensa en la Resolución 1368 adoptada tras los atentados del 11-S, pero lo cierto es que el citado consejo, que ahora el autor parece defender, pensó lo contrario. ¿También se equivocó el consejo? Mire usted las tropas que hay hoy en día en Afganistán... A lo mejor fue un error, pero el derecho internacional lo hacen los Estados, no la doctrina. Y es que tampoco estamos de acuerdo con el autor con la calificación que hace del carácter inmediato de la respuesta en caso de legítima defensa. No olvide que la inmediatez de la respuesta se forjó en el caso del Carolina que se refería precisamente a la legítima defensa preventiva. Según esa tesis, ¿Qué Estado podría hoy en día dar una respuesta realmente inmediata si se produce un ataque de una determinada consideración? Los tiempos cambian, y las respuestas también... Mire además el Informe de Alto Nivel sobre las amenazas, los desafíos y el cambio, de diciembre de 2004, 1levado a cabo a iniciativa del secretario general de las Naciones Unidas, en donde encontrará cosas muy interesantes, aunque no muy acordes con lo que usted defiende.

El señor Vallarta tampoco comparte la legalidad de las intervenciones humanitarias, aunque no sabemos si las considera al fin y al cabo legítimas o moralmente sostenibles. Ya se sabe que en este aspecto la doctrina está muy dividida.... El profesor Bermejo ha sostenido en numerosos trabajos que hoy en día el derecho internacional no puede prohibirlas siempre que se respeten determinados requisitos y se den determinadas condiciones. Y no es ni mucho menos el único, ni esto lo defiende sólo la doctrina anglosajona.... Autores como el profesor Virally o el profesor Sur, ambos franceses y eminentes internacionalistas, no han estado escasos de argumentos para defender esa clase de intervenciones. Y no es para menos, porque los derechos humanos fundamentales y las libertades están para que sean respetadas por los Estados. ¿Acaso usted está de acuerdo con lo que ocurría en Kosovo? ¿No reaccionaron una inmensa mayoría de Estados al unísono ante los crímenes que se estaban cometiendo? ¿Puede un Estado invocar su soberanía para cometer esos crímenes? ¿Qué hacer si el Consejo de Seguridad no puede adoptar una resolución? Preguntas como estas no figuran en su trabajo y hay que resolverlas antes de dar una respuesta... Ya sabemos que su trabajo no versa especialmente sobre eso, pero si se menciona, al menos hay que dejar constancia de ello. 
Por último, señor Vallarta, no añore usted el régimen de Sadam Hussein... Hoy en día los iraquíes han ido a las urnas a pesar de que algunos Estados y muchas personas hubieran deseado sotto voce lo contrario. ¿No se decía que en esas condiciones los iraquíes no irían a votar? ¿Cuántas veces ha sido insinuado esto por las Naciones Unidas, por Jacques Chirac y por otros? El actual Irak no es ningún paraíso, pero el profesor Bermejo le puede asegurar que es mucho mejor que el Irak que vio en su momento. Al margen de las opiniones que cada uno pueda tener al respecto, algo se ha conseguido... Y si no que se lo pregunten a los kurdos (gaseados en su tiempo, aunque no por los yankees) y a los chiíes de Irak (masacrados en 1991) que representan el 80\% de la población. Las elecciones en Irak han demostrado que entre la tiranía y el terror, y la libertad, ha ganado esta última, guste o no guste. 